\title{
ÉTUDE DE L'UTILISATION DE DIFFÉRENTES GRAISSES PAR LA TRUIE EN GESTATION
}

\author{
E. SALMON-LEGAGNEUR, D. W. FRIEND et L. GUEGUEN \\ Station de Recherches sur l'Élevage des Porcs, \\ Centre national de Recherches zootechniques, 78 -Jouy-en-Josas \\ Institut national de la Recherche agronomique
}

\section{RÉSUMÉ}

Huit truies adultes en gestation, placées en cage de métabolisme, ont été utilisées suivant un dispositif de double carré latin pour étudier la valeur alimentaire des quatres régimes suivants : I, témoin sans graisse ; II, I2 p. Ioo de graisses de coprah ; III, I 2 p. Ioo de suif ; IV, I 2 p. Ioo d'huile de maîs. Les digestibilités apparentes et corrigées pour l'excrétion endogène des acides gras totaux ont été respectivement les suivantes (p. Ioo) : I, I 2-92 ; II, 87-95 ; III, 79-92 ; IV, 8495. Les digestibilités des acides gras individuels varient avec la nature de la graisse, la longueur de la chaine et l'insaturation, mais après correction pour l'excrétion endogène, seules de faibles différences subsistent, à l'exception de l'acide stéarique, pour lequel on trouve les valeurs suivantes (p. Ioo) : I, 72 ; II, 57 ; III, 72 ; IV, 3I. La digestibilité de l'énergie et de l'azote et le coefficient de rétention azotée des différents régimes ont été les suivants (p. IOO) : I, 84-85-32; II, 87-88-36; III, 84-86-33; IV, 86-87-29 (différences significatives pour le lot II). On ne trouve aucune différence entre régimes pour la digestibilité du calcium et du phosphore. La valeur en énergie métabolisable des différentes graisses étudiées s'établit comme suit: coprah 8873 ; suif 7722 ; huile de maïs 8356 (calories/g).

\section{SUMMARY}

\section{STUDY OF THE, UTILIZATION OF DIFFERENT FATS BY THE PREGNANT SOW}

Eight adult pregnant sows were used in metabolism crates according to a design of double latin square to study the nutritive value of the following four diets : I, control without fat; II, I2 p. Ioo coconut fat; III, I2 p. Ioo tallow; IV, I 2 p. Ioo maize oil. The apparent digestibilities and those corrected for total endogenous fatty acids were the following (p. IOo) ; I, I 2-92; II, 87-95 III, 79-92; IV, 84-95. The digestibility of each fatty acid varies according to the nature of the fat, the lenght of the chain and the degree of unsaturation, but after correction for endogenous 
excretion, only small differences subsist between fat except for stearic acid showing the following values (p. Ioo) : I, 72 ; II, 57 ; III, 72 ; IV, 3I. The energy and nitrogen digestibility and the nitrogen retention coefficient of the different diets were the following : I, 84-85-32; II, 87-88-36 ;III, 84-86-33 ; IV, 86-87-29 (significant differences in group II). As for calcium and phosphore digestibility, no difference is found between the diets. The metabolizable energy values of the different fats studied are the following : coconut 8873 ; tallow 7722 ; maize oil 8356 (calories/g).

\title{
EFFETS DE L'INTRODUCTION DE SON DE BLE DANS UN RÉGIME A BASE D'ORGE CHEZ LE PORC EN CROISSANCE-FINITION, EN PRESENCE OU NON DE LITIÈRE
}

\author{
Y. HENRY, D. BOURDON et M. CHAMBOLLE \\ avec la collaboration technique de B. DABIEL \\ Station de Recherches sur l'Elevage des Porcs, \\ Centre national de Recherches zootechniques, 78 -Jouy-en-Josas \\ Institut national de la Recherche agronomigue
}

\section{RÉSUMÉ}

En relation avec l'extension des techniques modernes d'engraissement du Porc èn confinement, deux expériences ont été réalisées sur porcs en croissance-finition, afin d'étudier les effets de l'introduction d'un aliment cellulosique (son de blé), dans une ration à base d'orge et de tourteau de soja, sur les performances de croissance et la composition corporelle, en présence ou non de litière. La réduction de la valeur énergétique du régime de 3 roo à 2 goo kcal d'énergie digestible par kg, par incorporation de 15 p. Ioo de son de blé, chez le Porc nourri selon son appétit, se traduit principalement par une augmentation de l'indice de consommation ( 7 p. Ioo), accompagnée d'une légère dépression de la croissance en présence de paille (590 g/j contre 62I, entre 30 et $90 \mathrm{~kg}$ de poids vif), mais seulement pendant la phase de finition. Par ailleurs, l'introduction de ro $p$. Ioo de son dans le même régime à base d'orge, correspondant à un abaissement de la valeur énergétique à $3000 \mathrm{kcal}$ d'énergie digestible par kg, en l'absence de litière, permet d'obtenir des carcasses plus maigres, sans qu'il en résulte une détérioration de l'indice de consommation. 